\title{
Myelin Protein Zero-Like 1
}

National Cancer Institute

\section{Source}

National Cancer Institute. Myelin Protein Zero-Like 1. NCI Thesaurus. Code C33951.

Myelin protein zero-like protein 1 (269 aa, $29 \mathrm{kDa}$ ) is encoded by the human MPZL1

gene. This protein is involved in both ligand binding and signal transduction. 